\title{
7
}

\section{Legal education in transitional Vietnam}

\author{
Bui Thi Bich Lien
}

The launch of doi moi (literally meaning 'Renovation') has resulted in numerous unprecedented changes in Vietnam during the last decade and a half. Moving from a centrally planned society to a market-oriented society, the state has defined law as an important tool to govern society and promote economic development. This transformation process poses great challenges for Vietnam's legal system, as the ambitious targets set by doi moi need to be facilitated by qualified legal professionals.

In this context, legal education plays a critically important role. Although it is undeniable that law schools have made significant improvement in terms of teaching and establishing their prestige in society, the pace does not seem fast enough to accommodate legal reform (Legal Needs Assessment Report, 2002). Many practitioners think that the ever-increasing numbers of graduating law students lack the improved professional skills required to serve a transitional society. Despite a number of reform programs, the quality of legal training in Vietnam remains moderate.

This chapter analyses the status of Vietnam's contemporary legal education system, examining the influence of socialist legal doctrines on legal training, and attempts to evaluate the factors that induce resistance to reform.

The chapter starts with a brief description of the law school system and the law curriculum of Vietnam, with special attention on the legal theory subject and its significance to the entire course of study. The teaching and evaluation methods and their consequences are then examined. The efforts to reform legal education are explored, including formal programs launched by the national government and international donors and informal initiatives of law teachers. I will only discuss legal education at the tertiary level, focusing on Hanoi Law University and its 
training program as this is the largest training institution which plays a prominent role in legal education in Vietnam. Apart from written sources, my analysis is based on various informal interviews with law professors, law students, state officials and legal practitioners.

\section{LAW SCHOOL SYSTEM IN VIETNAM}

\section{A brief history}

Unlike other socialist countries with a relatively long tradition of law teaching (Macdonald 1980; Tay and Kamenka 1986; Gostynski and Garfield 1993), ${ }_{1}^{1}$ legal education in Vietnam has a brief, discontinuous history. During the French colonial period, public education was only accessible to a small élite group in large urban areas (Kelly 2000). A law school was established in 1941 with very limited enrolment of Vietnamese students, but there is no evidence that these early law graduates served in the legal education system after their graduation. ${ }^{2}$ The harsh period of war did not allow the government in the North to place emphasis on its legal process and training. There was a judicial training school that belonged to the People's Supreme Court, but it only focused on training judges on a small scale. The Ministry of Justice even had to close.

It was not until a few years after reunification that the Ministry of Justice was reopened and the Hanoi Law University (Dai Hoc Phap Ly Ha Noi, later renamed Dai $\mathrm{Hoc}$ Luat $\mathrm{Ha} \mathrm{Noi}$ ) was established as the first formal tertiary law school (see Sidel 1993). There was a law university in the South before 1975 (Dai Hoc Luat Khoa Sai Gon), but in 1976 it was merged with other schools of the old Saigon regime to form the Economic University of Ho Chi Minh City. This new university did not provide formal law training again until 2001. In 1989, Hanoi Law University opened its campus in Ho Chi Minh City. The founding teachers of this branch were sent from the North and were previously trained in the Eastern bloc. This campus was then separated from Hanoi Law University and became an independent law school of the South, the Ho Chi Minh City Law University (HCMCLU). ${ }^{3}$ As part of the changes brought by doi moi, law has become fashionable and many other institutions offering legal training have flourished.

In summary, legal education in Vietnam is a relatively new area and is largely disconnected from the previous non-socialist legal training. As a part of the national education system, it follows the mainstream track set by the Party and government for education and is consequently targeted at serving the socioeconomic development of the country. According to the Education Development Strategy for 2001-10, ${ }^{4}$ Vietnam aims to build a modern, scientific education system that is nationalistic in nature with a socialist orientation, based on the foundation of Marxist-Leninist theories and Ho Chi Minh's thought. ${ }^{5}$ Education's objective is to provide qualified human resources for the country's industrialisation and modernisation process. 


\section{The law schools and law teaching}

The current system of law schools and law teaching in Vietnam is complicated and operates under a number of different forms of administration.

Until the end of the 1980s, Vietnam copied the Soviet education model (Financial Times Information 2002), including two main types of universities (Kelly 2002). The first type, 'specialised universities', such as Hanoi Law University and HCMCLU, focus on a single area of study. These universities are established specifically to train law graduates. Hanoi Law University is the largest law training institution in Vietnam and a subordinate body of the Ministry of Justice. Meanwhile, HCMCLU is under the administration of the Ministry of Education and Training (MOET) (Hanoi Law University 2002), and has quickly established its reputation in the South since becoming independent from Hanoi Law University.

Apart from Hanoi Law University and HCMCLU, universities exist that specialise in other disciplines but which also include a law subject in the curriculum for their non-law students (Hanoi Law University 2002). ${ }^{6}$ These universities have a team ( $\mathrm{To}$ ) of law lecturers (often a small team) and the courses they teach only provide basic introductions to law. ${ }^{7}$

The second type of universities are 'multi-disciplinary' and offer degrees in different areas, including law. These universities have a Faculty of Law (Khoa Luat), most of which were established very recently. ${ }^{8}$

In addition, there are other legal training institutions administered by a research institute or judicial body. These institutions may offer postgraduate law education or focus on legal professional skills training. For example, the Institute of State and Law (under the National Centre for Social and Human Sciences) and the Faculty of State and Law (under the Ho Chi Minh National Political Academy) are authorised to conduct postgraduate law education. Meanwhile, the Higher School of Procuracy (under the People's Supreme Procuracy) and the Legal Professional Training School (under the Ministry of Justice), later renamed the Judicial Academy, train judges, private lawyers and procuracy cadres.

In the early 1990s, Vietnam adopted new forms of tertiary education. 'Peoplefounded universities' (dai hoc dan lap) and 'open universities' (dai hoc mo) were established as a part of the education reform program. Some of these universities also took part in legal education, but most of their resources, such as lecturers and materials, were drawn from other state law universities on a contractual basis. This type of law training, however, soon ceased because of government concerns over quality.

\section{Law programs}

Law training institutions in Vietnam offer a variety of programs, which can be categorised into three main groups.

The first category is applicable to regular full-time students (sinh vien chinh quy dai han) who engage in undergraduate education. After completing a four or five 
year course, students receive a formal Bachelor of Laws degree (bang dai hoc chinh $q u y$ ). Despite tough competition for admission, the number of students enrolled in these courses has increased markedly. ${ }^{9}$ In response to the recent popularity of offering several university degrees, some law training institutions have initiated 'second degree courses' (often known as 'lop bang hai') that provide formal Bachelor of Laws degrees for students who have a degree in another field..$^{10}$ These courses are often shorter than the regular program and students are not required to attend classes on a daily basis.

The second category is 'in-service' (tai chuc) education. ${ }^{11}$ Similar to the Chinese model (Depei and Kanter 1984), in-service training was initially designed for state officials who had not previously undertaken formal education. Students continue to work and attend classes on a part-time basis. They also receive a Bachelor of Laws degree that is specifically issued for in-service courses (bang dai hoc tai chuc); such a degree is essential to ensure promotion and job stability. These courses have been expanded to non-state participants due to the decreased demand in the state sector recently. In-service training has been acknowledged as a helpful way to upgrade state officials' knowledge of basic laws and make legal education more accessible to the population. The popularity of this law degree, ${ }^{12}$ however, has induced some doubts about its quality. The number of courses is excessive for law teachers, leaving them no time to prepare and update their materials. In addition, a less-valued degree (Certificate of Higher Education in Law or 'bang trung cap luat') is available for students who only have a basic educational background.

The third type of law program is postgraduate education, which was initiated in 1986 by the Institute of State and Law. Since then, some other institutions, such as the Hanoi Law University, have also begun providing Master and Doctoral degrees in law, and the number of postgraduate students has promptly increased. ${ }^{13}$ Many, however, hold the view that this upgrading program does not mean that legal academia in Vietnam is developing. Postgraduate students are concerned that curricula are very similar to those used in the undergraduate programs, and that the courses do not provide them with improved research skills and methodology.

\section{Law curricula}

The fact that there are different training institutions providing different law courses does not mean that the law curricula vary. The tension between the increasing demand for a law degree and the lack of resources makes legal teaching heavily dependent on a relatively small number of law teachers and the materials prepared by them. By the end of the 1980s, and during the 1990s, lecturers from Hanoi Law University were intensively mobilised to teach law courses throughout the country. Law textbooks published by Hanoi Law University have also been used widely in other institutions. Although there have been moves to diversify, most of the law schools still share the same syllabus. As such, I will limit my discussion to the undergraduate curriculum studied by full-time students at Hanoi Law University, 
due to its popularity. ${ }^{14}$ I will not refer to the curricula for in-service training, ${ }^{15}$ postgraduate and other legal training courses. In addition, my analysis will focus on particular subjects in the curriculum that reflect how socialist legal theories affect the style of law teaching.

Although the length of the course has been changed from time to time, ${ }^{16}$ the substantive teaching has not materially changed during the last decade. It looks similar to the curricula followed in other socialist law schools. ${ }^{17}$ Marxist-Leninist studies remain compulsory and Soviet legal doctrine decides the design of the entire curriculum. It should be noted, however, that many new subjects have been added to the training program in an effort to bring law education closer to the market place.

The program consists of two phases: fundamental training (dao tao co ban) and specialised training (dao tao chuyen nganh).

The fundamental training period is mandatory for all law students. For social and humanities studies, it adopts the MOET standards, which obviously have a socialist orientation. Following the introduction of the Education Development Strategy, the prime minister issued a decision in 2002 requiring all universities to invest more human and financial resources in the teaching of Marxist-Leninist theories and Ho Chi Minh's thought. It reconfirms that study of Marxist-Leninist philosophy, political economy, socialist science and history of the Communist Party of Vietnam are compulsory for all university students. From 2004, law students learn the new subject of Ho Chi Minh's thought. ${ }^{18}$ Fundamental training in the law schools includes all these topics.

Apart from Marxist-Leninist studies, some other subjects, including physical education (the duc), national defence education (quan su) and foreign languages, are also taught in this first phase. The time allocated for fundamental training is approximately 30 per cent of specialised legal training (Hanoi Law University 2002). ${ }^{19}$

The specialised legal training focuses on teaching law and other law-related topics. Students learn Marxist-Leninist theories on state and law (ly luan nha nuoc va phap luat) and all law branches (nganh luat). Each law branch constitutes a mandatory subject. Examples include constitutional, administrative, criminal, civil, economic and labour law..$^{20}$ In addition, supplementary and optional subjects are offered separately to students of different departments ${ }^{21}$ depending on their 'specialisation' (chuyen nganh). Most of these subjects are closely related to the development of a market economy. For example, students in the economic law department take business administration, auditing or securities laws, while students in the international law department study international trade law and international settlement. Although these additional subjects themselves are still influenced by socialist ideologies, the fact that they are included in the curriculum shows a compromise between socialist orientation and a reaction to market needs.

At the end of specialised training, students are sent to different institutions and organisations for an internship to gain some practical experience..$^{22}$ 
The fundamental training phase is generally controlled by the MOET, while Hanoi Law University has more power in specialised training. Following the timeframe set by the MOET, Hanoi Law University decides on the number of law topics that can be taught and the time allocated to each topic. Changes to the law curriculum, such as the introduction of new subjects or expansion of teaching time, must be approved by the Science Committee (Hoi Dong Khoa Hoc) of Hanoi Law University and the Ministry of Justice.

\section{THEMES OF STATE AND LAW}

Themes of State and Law [Ly Luan Nha Nuoc va Phap Luat] provides background knowledge on state and law for all law students and is regarded as the conceptual framework in which law is analysed (Le Minh Tam 1998a). As such, it is intended to establish a foundation for law students to deal with legal issues.

The main source of materials used for teaching and studying is a textbook of Themes of State and Law. Although it has been updated and revised many times and is now much more comprehensive than it was ten years ago, some basic concepts remain unchanged. Notably, the class nature of state and law, and the approach that law is an instrument of the state to govern society, have been reaffirmed ${ }^{23} \mathrm{In}$ addition, Party leadership is among the guiding principles that controls state governance and lawmaking activities (Le Minh Tam 1998c).

Students are taught that the most important function of the state is to manage the economy ('quan ly nha nuoc ve kinh te'). ${ }^{24}$ State economic management is regarded as a part of the class revolution during the transitional period ('dau tranh giai cap trong thoi ky qua do') to protect the working class from exploitative capitalism. To fulfil this task, the state employs plans ('ke hoach'), builds up a 'mechanism of economic management' ('co che quan ly kinh te') and owns essential production tools ('tu lieu san xuat chu yeu'), including land (Le Minh Tam 1998d). ${ }^{25}$ Since the subject is taught to law students soon after they enter law school, when their legal knowledge is still limited, ${ }^{26}$ these ideologies of state economic management are often well rooted and continue to develop during the four-year course.

As mentioned earlier, Themes of State and Law divides the legal system into independent law branches (nganh luat doc lap). This theory has been the core element that forms the law curriculum. It is based on Marxist arguments of the relationship between the superstructure and infrastructure. Social relations (quan he xa hoi) that are subject to law adjustment (known by legal scholars and law students as 'objects of adjustment' or 'doi tuong dieu chinh' ) are part of the infrastructure, while the law belongs to the superstructure.

Once social relations are governed by laws, they become 'legal relations' (quan he phap luat). Social relations occurring in a particular field, such as labour or finance, share certain common features. Therefore, they can be categorised into the same group. As a consequence, the laws governing such groups are similarly categorised. 
Two standards are used to define the independence of a law branch, namely 'objects of adjustment' and 'methods of adjustment' (phuong phap dieu chinh) (Le Minh Tam 1998f:393-94).

The most noticeable disadvantage of this classification theory is that it understates the complexity of the legal system. The 'independent law branch' approach has, to some extent, isolated the 'branches' of law from each other. ${ }^{27}$ As learners, law students tend to be attached to simple formulas and channel all legal issues into one (or a few) of the laws that they know. This, in turn, affects their ability to identify a matrix of legal matters that are often associated with social relations. For example, students learn about companies and administrative procedures to set up such entities under economic law. They then learn about land law, tax law and labour law as separate subjects. This way of teaching fails to make students aware that the existence of a company not only involves its establishment formalities, but also involves a series of other complicated legal issues such as land, tax and employment. The compartmentalisation does not prepare students to offer clients practical advice.

Students also face great difficulties dealing with other aspects of the legal system that do not fall into any of the standard law branches, such as import and export regulations and customs laws. Even law teachers tend to limit their knowledge to their 'specialised' topics and the series of issues that are set for teaching within those topics. For example, land law teachers would generally not be interested in researching how land is taxed, as that issue is dealt with by finance law teachers.

Classification theory is also a source of confusion and ambiguity. Legal scholars informally admit that there are numerous social relations that cannot be categorised into any of the current law branches. Even some traditional legal relations, such as contracts, have new forms. ${ }^{28}$ As such, law teachers struggle to invent some common features that can represent 'objects of adjustment' of a law branch and maintain their 'independence' from each other.

It is even harder to justify the 'methods of adjustment' proposition. There are only two 'methods of adjustment' that apply to the entire legal system, namely the 'compulsory method' (phuong phap menh lenh) and the 'equal method' (phuong phap binh dang). It is believed that the 'compulsory method' is suitable for governing vertical legal relations in which the state is one party, such as administrative or criminal laws. On the other hand, the 'equal method' is applied to horizontal relations in which the parties enjoy equal status, such as civil law. Since doi moi, all law branches that govern economic activities employ both methods. Therefore, the second element that determines the 'independence' of these branches arguably no longer exists. Although legal writing and teaching has focused less on the reasoning behind the categorisation of the legal system, ${ }^{29}$ classification theory is still a part of the formal teaching program, so it continues to generate confusion among teachers and learners.

Themes of State and Law seems to mitigate the interweaving of law and other social spheres. The relationship between law and politics, economics and morality 
is only briefly addressed (Le Minh Tam 1998d) ${ }^{30}$ and is not mentioned again in other law subjects. Thus, students encounter ideologies of instrumentalist law and state management most frequently since these issues are repeated throughout the course. This is another weakness of legal education, since students do not learn about the sophistication of the legal and political system and how law interacts with economic and political development.

Themes of State and Law does not yet reflect the 'nationalism' feature. There has been a series of scholarly discussions about Ho Chi Minh's thought on state and law, but none of this discussion has been introduced to law schools since law teachers are not yet ready. It is expected that this issue will be covered by the new subject of Ho Chi Minh's thought and will be taught by teachers of political science. ${ }^{31}$ As such, socialism remains a dominant feature of state and law doctrines.

The following sections will use some law 'branches' as examples to examine further how themes of state and law are incorporated into other law subjects. Although there are currently more than a dozen law branches, a standard model applies to all of them. The first one or two lessons are devoted to providing a theoretical basis to students. This introductory session presents an overview (khai niem) of the subject and sets out its scope. Largely based on classification theory, it shows how branches are independent from others.

\section{Land law}

Land law is claimed to be different from other laws (in particular civil and economic law) because it has its own 'objects of adjustment' and 'methods of adjustment'.

The 'objects of adjustment' have two salient features. First, land is a 'special commodity' (hang hoa dac biet) and therefore social relations concerning land (quan he dat dai) are not subject to civil law that governs regular property. This original concept of 'land as a special commodity' is intended to preserve state ownership of land. It remains ambiguous and unclear, as there is insufficient explanation of what makes land a 'special commodity'. Second, land relations are not a type of economic activity since the management and use of land is for community interests rather than for making a profit. Thus, they are not ruled by economic law either. 'Methods of adjustment' is a combination of the 'compulsory method' and the 'equal method' (Tran Quang Huy 2001a:12-16).

The application of the classification theory to land law is confusing because there are certain 'land relations' that do not fit into the ideological framework of 'objects of adjustment'. For example, it is hard to explain why land transactions are not economic activities when they are subject to capital gains tax. In addition, its 'methods of adjustment', as noted earlier, are not different from those of other law branches and therefore cannot be referred to as a distinguishing feature of land law.

Land law also embodies the fundamental principle of Marxist theory that land belongs to 'the people'. Two entire chapters are devoted to state ownership and management of land (quan ly nha nuoc ve dat dai) (Tran Quang Huy 2001b:47-76, 2001c:77-110). These chapters reaffirm the themes of state and law and build up the 
important ideology of state management in relation to land. On the other hand, land law is extended to include a number of lessons on land transactions in recognition of the realities of the market. However, land law teachers rarely question the contradiction between 'state management' and the largely uncontrolled land market in their teaching.

\section{Finance law and banking law}

These two subjects are an interesting example of how legal theories and the law curriculum have been adjusted to address economic reform. In the past, they were a single law branch under the name of finance law. Under the central planning regime, finance law governed vertical relations, including budget and tax laws. There were also some insurance and banking regulations but all the insurance companies and banks were state-owned.

The doi moi policy and changes in the financial services sector meant that the classification theory was no longer relevant to this law branch. New horizontal relations such as commercial insurance and commercial loans have emerged, prompting law teachers to create a new subject of banking law. The reasoning for this split, however, was still based in the traditional themes of state and law. It was seen that banking law needed to be 'independent' because it has its own 'objects of adjustment' that differ significantly from those of finance law.

Finance law was designed to govern a mixture of vertical and horizontal relations including budget and tax, corporate finance and insurance. ${ }^{32}$ Since it is difficult to find common features that represent these groups, scholars changed the approach to list them all as 'objects of adjustment' of finance law. A similar path was adopted for banking law. Although banking law has been made a new subject, law teachers informally and reluctantly acknowledged the unconvincing theoretical basis for its independence. Finance law later was further split into four separate topics; namely, tax law, budget law, commercial insurance law and securities law. All these subjects are still handled by the same team of finance and banking law teachers. However, the concept of 'methods of adjustment' is deliberately silent in the teaching.

As with land law, students learn about state management in the finance and banking sectors (quan ly nha nuoc trong linh vuc tai chinh va ngan hang). ${ }^{33}$ Although it is not entirely clear, state management is usually referred to as the theoretical basis of almost any exercise of state power. For example, the state management function of the State Bank of Vietnam was invoked to explain why the bank should issue regulations setting a ceiling rate for offshore loans. Later, when the ceiling rate was removed, justification was attributed to the bank's discretion to create a more liberal lending policy for the purpose of state management at that time.

If Themes of State and Law introduces the first basis for state management, other law subjects work to consolidate it. When law students reach their final years, the concept has become firmly established. They tend to utilise it to justify virtually all legal issues that arise from state intervention into social relations and, significantly, tend to develop a mentality that assigns priority to state rights and devotes insufficient 
attention to other parties' interests. In a moot tax case, for example, a student representing - and supposedly defending - a taxpayer, apologised to the tax authority because he felt the principle of state management was being violated.

\section{Design of curricula and course materials}

Law curricula for the specialised training phase are prepared by law schools. The first generation of law teachers-now quite senior-was trained in Eastern Europe and is currently the primary force in designing the curricula and writing the textbooks. Due to the lack of resources during the 1980s and early 1990s, course materials, especially the socialist legal doctrines and concepts, were prepared according to law teachers' overseas experiences.

Following doi moi, Themes of State and Law and other economic law subjects have been updated to address economic reform. However, changes in law curricula and course content have been relatively slow compared to other disciplines such as economics or other social sciences. Arguably, this can be attributed to the fact that the conceptualised understanding of law-according to which the law is supposed to demonstrate and cement the Party's policies-remains unchanged. As such, the Themes of State and Law have mainly been developed on the basis of Party policy documents. Since the Party's policies promote a socialist legal system (he thong phap luat xa hoi chu nghia) in Vietnam, Soviet legal orthodoxies are employed to serve this purpose. For both law teachers and law students, law is an integral part of politics, and the study of state and law is incomplete without referring to the Party's resolutions. ${ }^{34}$

Despite awareness of the need objectively to re-examine the relevance of Soviet legal doctrines in a market economy, law teachers refrain from challenging these entrenched theories. They tend to 'reform' the technical rather than the theoretical aspects of law teaching. This tendency is partly due to the lack of proper research skills and methodologies. However, in many cases teachers are reluctant to touch upon theories because of concerns over political sensitivity. In certain situations where Soviet doctrines appear to be particularly irrelevant, they avoid them by focusing on the practical issues.

While law teachers and scholars were free to adopt Socialist legal writing to prepare their teaching materials, they used legal materials from Western market economies for different purposes. In the latest version of the Themes of State and Law textbook, some brief references to US constitutional writing were inserted as examples to illustrate Soviet concepts of state and law. Experience of other Western legal systems has also been sought, but the focus has been on neither doctrines nor concepts.

For example, when banking law was split from finance law, teachers with Australian and British educational experience were consulted on the question of how banking law is treated in these countries. Banking law eventually became an independent subject for teaching partly because of the adoption of a model learned from other developed legal systems (Vo Dinh Toan 2002). However, the classification 
theory was still used to justify this movement, and references for banking law still include Soviet legal writing from the 1950s and the 1970s (Vo Dinh Toan 2002). Law teachers are urged to introduce the Western experience in certain areas of banking law, such as bank guarantees or syndicated loans, but they are also required to teach the principle of state management of the banking system. It is therefore clear that reformists are reluctant to move away from the politically dominant theme.

Collective decision-making is another factor that may have contributed to resistance to reform of curricula and course materials. Each law subject is often taught by a group of law teachers who work independently to prepare their lecture notes and reference materials. Such materials, however, are required to conform to a standard textbook. New ideas or approaches need to be discussed and approved by the whole team in order to ensure consistency and consensus. While this system aims at compromise and harmonisation, it discourages the introduction of radical views, because their introduction is usually a source of conflict. Teachers tend to avoid presenting individual opinions or controversial views to students because it may cause colleagues to lose face, or expose the team's internal inconsistencies publicly.

\section{Teaching and evaluation}

Teaching methodology. Most universities in Vietnam, including law teaching institutions, apply the traditional lecturing style. This method is characterised by one-way communication in which the teachers deliver their lectures while students take notes. There is virtually no interruption for questions or comments from students. Lectures are usually long and classes are large..$^{35}$ Junior lecturers are required to attend a course on teaching methodology and skills when starting their careers, and the instructors for this course are from a pedagogy school that emphasises oneway communication and discourages student participation.

Teachers prepare their own lecturing materials, but such materials need to follow standard textbooks to ensure consistency in terms of structure and content. Radical and active teachers may search for external sources such as Western law or even materials used by the Saigon Law School before 1975, but access to these sources is often limited and depends on individual initiative. Most of the law lessons are based on legislation and, as such, can easily become outdated once the legislation changes. Although considerable investment has been put into upgrading teaching and learning facilities, legal updates are often received late by law school libraries. Teachers tend to use their own personal relationships with state officials to obtain new legal documents.

Seminars are also arranged in parallel with lectures. As part of wider reform efforts, the time allocated for seminars has been increased and classes made smaller ${ }^{36}$ to give students more opportunities to take part in discussion (Hanoi Law University 2002). This form of teaching is also not very effective, however, as student participation in discussion is often limited. In a typical seminar, teachers have to try hard to get students to speak. This may reflect Vietnamese cultural norms-in 
Confucian societies, where education is highly appreciated, students are taught to respect teachers and their opinions. After many years spent in school, they fall into the habit of obeying teachers and following their instructions, and, as a consequence, tend to be shy of presenting their own opinions in public. For those who are confident and outspoken, there is a concern that their perspectives may not be the 'right' ones.

Generally, a seminar is not a forum where students learn how to debate and argue. Rather, it is a modified form of lecturing in which students wait for the right answers and resolutions from teachers. In other words, students rarely work towards a solution for legal problems and their contribution to the outcome of a seminar is minimal. Hypothetical cases are included for discussion, but tend to be relatively simple. Court cases are not yet available from public records, therefore teachers have to be inventive with their own cases.

The biggest disadvantage of this teaching style is that it produces passive learning. Neither the lectures nor the seminars train law students in the problem-solving and analytical skills that are essential for the legal profession. Although reformists have called for the launch of new teaching methods that focus more on skills training, law teachers are confused and torn between traditional lecturing and case studies. ${ }^{37} \mathrm{Like}$ students elsewhere, students in Vietnam are most concerned about how to pass exams. As the exam scheme (discussed below) focuses on rote learning, students are forced to develop memorising skills. Creative and independent thinking is not promoted and most law graduates are still needlessly immature in this respect after graduation.

Another noticeable shortcoming is the big gap between what is taught at law schools and what is required in legal practice..$^{38}$ Although many law teachers are admitted to the bar, only a small number have actually represented clients before the courts or engaged in providing legal consultancy services. ${ }^{39}$ The new regulations affecting lawyers have worsened the situation because the legal profession and law teachers are separated indefinitely. According to these regulations, government officials cannot become members of the bar, apparently to avoid conflicts of interest, and those who represent state power cannot simultaneously serve private clients. Since law teachers also have the status of civil servants, they are not allowed to join the bar. From 2004, all law teachers who had previously been admitted to the bar were to quit the bar if they wished to stay with universities. ${ }^{40}$

There have been some arguments that the current methodology applied to law teaching in Vietnam has been influenced by the French style inherited from the French civil law system. However, law teachers who graduated in the Eastern bloc reported that the current teaching style in Vietnam is exactly what they experienced in other socialist law schools.

Although law teachers and students have informally admitted the ineffectiveness of the current teaching methodology, there has been no focus on developing legal trainers' skills. Analysis in the next section will show that legal reform programs at both national and institutional levels assign only an insignificant position to legal education. Meanwhile, government policy on tertiary education demonstrates a contradictory approach to the issue of teaching methodology. Unprecedented by- 
laws for universities have been issued to promote decentralisation, but at the same time a certain degree of control has been retained. ${ }^{41}$ On the one hand, the recent Decision No. 153 entitles lecturers to choose teaching materials and teaching methodology freely in order to promote their individual ability and quality of teaching. On the other hand, teachers are obliged to teach in accordance with curricula and course content designed by MOET and universities. ${ }^{42}$

Since law belongs to the superstructure and is regarded as a state instrument to govern society, the exercise of law is not seen as part of the economic base. Rather, it is a demonstration of state power. Therefore, the concepts of 'legal profession' (nghe luat su) and 'legal services' (dich vu phap ly) are barely mentioned in legal teaching. This ideology fits with the current institutional structure, where lawyer skills are only taught in a special course which is designed for legal professional training. ${ }^{43}$ In addition, professional qualities are often matched with political qualities as law and politics overlap.

The 'general objective' (muc tieu chung) of legal training at Hanoi Law University is defined as follows.

The law program aims at training law graduates with political and moral qualities and consciousness to serve the people. Law graduates should have knowledge and capacity to perform their jobs. In addition, they should have good health to meet the demands of the country's modernisation and industrialisation process. They should also contribute to the building of a law-based state, aiming at prosperous people, wealthy nation and civilised society [emphasis added]. ${ }^{44}$

The 'political and moral qualities' are positioned as primary targets for legal education. In addition, the requirement that law graduates should have consciousness to serve the people implicitly refers to a socialist state which is 'of the people, for the people and by the people', as defined in the constitution. ${ }^{45}$ Other references to modernisation and industrialisation only operate at a high level and thus do not present any particular policy instructions to law teaching.

To achieve this general objective, the policy draws certain specific objectives (muc tieu cu the) for legal education

- to provide students with fundamental, comprehensive knowledge about law and the legal system

- to provide students with other law-related social knowledge

- to equip students with scientific mentality and approaches to resolve theoretical and practical legal problems

- to form preliminary concepts about legal expertise in different areas

- to acquaint students with the operation and activities of different institutions so that when they graduate they will be equipped with fundamental legal and practical knowledge, and be able to find and resolve common problems that arise in specialised areas in which they are trained. In addition, they will have a foundation to pursue a higher degree in law.

It is a common understanding among law teachers that 'fundamental knowledge' (kien thuc co ban) is limited to the theoretical (ly thuyet), rather than the practical side 
of law and, as such, does not relate to the development of professional skills. They argue that law graduates will develop their own problem-solving skills once they start their careers and deal with law in practice. Although the policy requires training in 'practical skills' (ky nang thuc hanh) for students, it simply refers to a preliminary understanding of how institutions (co quan, to chuc) operate in practice. In the Vietnamese context, these institutions often mean state organisations such as the court, the inspector office or state-owned institutions. Practical skills are in fact gained when students perform a brief internship in such institutions, rather than in the law school. In addition, the skills acquired frequently concern the exercise of state power using law.

The comprehensive report about legal education in Vietnam completed by Hanoi Law University in 2002 also mentions the need to target professional skills training for law students. Its main focus, however, is the curriculum and no reference is made to teaching methodology.

\section{Exams and assessment}

The assessment methods applied in legal education share some common problems apparent in the entire education system of Vietnam. The borrowed Soviet model, spoilt by the local achievement-craving mentality, often leads to dishonest evaluation (Financial Times Information 2002). Different kinds of exams have been trialled, but none seem to be effective in ensuring quality and fairness. In traditional closedbook exams, copying and plagiarism are rampant as students are challenged to memorise large volumes of materials in a few days and seek ways of avoiding this. Open-book exams were trialled, but most papers were returned with the same answers. Oral exams have recently been promoted in a reform effort (Hanoi Law University 2002), but the result has not been overly different and the experiment discomforted both students and teachers. As with closed-book exams, students memorise huge amounts of material, including textbooks, lecture notes and legislation for the oral exams, where they are given a brief time to answer a few questions that constitute a very small part of what they have worked hard to memorise. The teachers, on the other hand, are required to follow a series of assessment instructions which are difficult to apply in practice. Despite strict rules, informal lobbying for good grades is common in both written and oral exams.

\section{LEGAL EDUCATION REFORM}

\section{National reform}

At the national level, attention to law training reform appears to be modest. In addition, the Party's policy for reform focuses more on management and control than on accommodating legal education to legal and economic development. 
Resolution No.08/NQ-TW introduced by the Politburo in January 2002 is an important policy document that sets out a series of institutional reforms for the legal sector. However, it only briefly mentions legal education as a part of the capacitybuilding program. In particular, the resolution requires tertiary law training to be concentrated in Hanoi Law University and HCMCLU, and calls for unification of curricula and law textbooks. The objective of this reform is to ensure that law graduates will have a firm political view (quan diem chinh tri vung vang), high values of morality (pham chat dao duc tot) and be professionally qualified. It is unclear how the institutional and curricula restructuring will help reach this objective.

Following the resolution, the prime minister issued Directive No.10/2002/CTTTg in March 2002 with instructions for implementation, prodding the MOET and the Ministry of Justice to restructure legal training institutions, with a focus on Hanoi Law University and HCMCLU. In addition, it instructs the two ministries to work on a proposal to unify law curricula and textbooks nationwide. The directive does not provide further guidance, and it is up to the discretion of the two ministries to fulfil the instructions.

Restructuring the curricula is one of the first steps that the Ministry of Justice and Ministry of Education have taken to implement the program, with a committee of experts having been formed to work on the issue. Reformists within the group have suggested a modernised curriculum with a Western influence. This approach faces certain tensions and concerns as the majority of the committee were either trained in Eastern Europe or were locally educated. In addition, it exposes some groups of teachers to unfamiliar topics while others have to reduce their lecturing time ${ }^{46}$ For example, there was a proposal that the commercial law subject should also cover insurance regulations. Meanwhile, commercial law teachers have never taught insurance law, as it is regarded as a part of finance law.

In addition to the judicial reform program, the government of Vietnam, following recommendations made by the International Consultative Group in December 2000, established a national inter-agency team to conduct a comprehensive Legal Needs Assessment of the country's legal system. It was intended that the Legal Needs Assessment would serve as a basis for developing a strategy for the development of Vietnam's legal system through until 2010. The inter-agency team, led by the Ministry of Justice, was divided into small groups researching different areas of the legal system, including law training.

The Legal Needs Assessment Report acknowledged the importance of legal education by positioning it as a crucial component of the legal system. Based on the examination of the current status, achievements and shortcomings of legal education, the report provided a set of goals to develop the national law-training regime in the next ten years, as well as an action plan to reach such goals. It was the first time that the country's legal education system and its role in legal reform had been evaluated nationally ${ }^{47}$ The Legal Needs Assessment was rejected after several rounds of reviews and revisions, however, and a new policy document, the Legal System Development 
Strategy, was introduced in early 2003. Unlike the Legal Needs Assessment, the Legal System Development Strategy takes the same approach as Resolution No. 8 and places negligible importance on legal education reform. There has been no formal explanation for this shift of focus. ${ }^{48}$

\section{Development projects supporting legal education}

Since the early 1990s, reform of Vietnam's legal sector has become attractive to international donors. Many projects have been specifically designed to support legal education.

Together with projects in the area of administrative reform, ${ }^{49}$ projects promoting law reform are subject to special governmental control. Regulations on management of international cooperation in the legal sector ${ }^{50}$ set out a number of principles for such cooperation. Among other things, law projects must be implemented on the basis of ensuring national sovereignty and respecting local culture. In addition, they should fit within the socioeconomic development policies of the Party and the state. The regulations also establish appraisal and approval procedures for all law projects, including those on legal education. Training institutions like Hanoi Law University are not allowed to have direct relationships with international partners without going through the Ministry of Justice. This filtering regime has resulted in a limited number of projects supporting legal training during the past decade, in comparison to other disciplines. The new by-laws for universities ${ }^{51}$ have liberalised this aspect by authorising local universities to set up cooperation programs directly with foreign partners. It is, however, unclear how the conflict between this new bylaw and the old regulations will be resolved. ${ }^{52}$

When foreign assistance actually occurs, its impact on local legal education seems to be insignificant. For example, Hanoi Law University, as the largest law training institution in Vietnam, hosts a 'Vietnam-France Law House' (Nha Phap Luat VietPhap) on campus, which provides library facilities for French language readers and organises seminars on various legal topics. However, the influence of the House seems to be modest given the small French-speaking population in the school. The use of materials and ideas that arise from the seminars is also limited as teachers are still bound in their teaching by the Soviet legal theories and standard textbooks.

Perhaps the most noticeable foreign project is that provided by the generous Swedish International Development Agency. A formal cooperation program has been established between Hanoi Law University, HCMCLU and a Swedish university to improve curricula, teaching capacities and facilities. Seminars have been held and a number of Vietnamese law teachers have gone to Sweden for short and longterm training. ${ }^{53}$ Nonetheless, the project remains remote to the educational life at Hanoi Law University. Workshops on teaching methodologies were held but only attended by a small audience of lecturers. After several years in operation, the project's contribution to the improvement of curricula and teaching quality at Hanoi Law University seems to be modest given its relatively large size. These facts have 
yielded some concerns about the effectiveness of foreign assistance in Vietnam. As Zamboni (2001) noted, this kind of project needs to invest more resources to investigate and scrutinise the actual conditions of the local counterparts.

In addition to formal projects at Hanoi Law University, a number of teachers have benefited from other scholarship programs and have been trained at Western universities. Despite their experience, they remain inactive not influential on their return due to a number of concerns.

\section{Other reform efforts}

Apart from the above top-down programs, some bottom-up changes have also emerged, better reflecting local conditions. Examples below of reforms to the curricula and teaching methods are taken from Hanoi Law University.

At Hanoi Law University, more activities have recently been added to the formal teaching program to engage students in public discussion and debate. Moot courts (phien toa tap su) and quiz competitions (cuoc thi) $)^{54}$ are organised occasionally. Some new research centres have been established to promote research activities, such as the Centre for Commercial and Investment Law (Trung Tam Phap Luat Thuong Mai va Dau $T u$ ) within the Department of Economic Legislation. However, the activities of these centres remain limited as they are not set up as independent units and are therefore not free from control of the department. A new Centre of Comparative Law was also established at university level, but it has experienced difficulties due to a lack of staff and other resources.

A minor project initiated by the Department of Economic Legislation studied the needs of reforming economic law (luat kinh te). The question posed by the organiser was whether 'economic law' should retain its current name or whether it should have a new name that better reflected its substance. The two alternative names chosen were 'business law' (luat kinh doanh) and 'commercial law' (luat thuong mai). In addition, researchers were asked to consider the content of economic law. Diverse opinions expressed in a workshop that reported the results of the project showed how, within the context of legal academia, the traditional Soviet idea of economic law was being challenged by market influence. Though consensus was reached on the importance of reforming the subject, scholars presented different views and perceptions on the issues. Some supported the removal of the name 'economic law' by looking at the experience of the neighbouring Chinese. Senior scholars who were trained in the former Soviet Union described how the idea was imported into Vietnam. They believed that 'economic law' was a mistranslation of Soviet terminology during that transplantation process. A Western approach to commercial law was also introduced as a suggestion for reform. A more pragmatic view cautiously warned that attention should be paid to substance rather than terminology, to avoid the common problem of 'new jar, old wine' ('binh moi, ruou cu'). According to these scholars, it was more important to apply new teaching methodologies and make the subject more practically applicable rather than simply change its name. ${ }^{55}$ 
The frequently mentioned reform idea of 'modern teaching methodology' (phuong phap giang day hien dai) also engages a number of radical law teachers in the search for such a method. Collectively or individually, they have tried to experiment with case studies in their teaching. A survey on teaching methodologies was conducted by the Department of Economic Legislation of Hanoi Law University to gather teachers' (mostly junior lecturers) opinions on the issue. Following the survey, a workshop was held to report on the results. Since this event was not formally initiated by the Department or Hanoi Law University, the organisers looked to the Youth Union as a sponsor.

The workshop stirred hot debate about the definition of a 'case study' (phuong phap tinh huong) and the 'regular' or traditional way of teaching (phuong phap thong thuong). Since most junior teachers are locally trained and have never been exposed to Western training, they were confused about case studies. There was a question whether illustrating examples used in a lecture is a form of case study. Others asked whether a single case should cover most of the legal issues addressed by a law subject. For example, should a single labour case include employment, compensation, strike and dispute settlement issues. Obsessed by the power of modern technology, many believed that the use of slides and projectors is also a new method for teaching (so-called 'projector method' or 'phuong phap den chieu'). Although the workshop was only an informal reform effort that did not attract much attention from the University authority, it represented the real needs of those who participate in legal education on a daily basis.

\section{CONCLUSION}

Observers have been concerned about the failure of legal education in Vietnam during the last one and a half decades. Only three to four per cent of law graduates are finding work in the legal system (Quinn 2002), ringing alarm bells about the law training reform process.

The above analysis has indicated how traditional Soviet legal doctrines and teaching methods affect the quality of training. While state authorities and legal practitioners deal with market participants on a daily basis, law schools are still largely isolated from the process of economic and legal development. Legal academia remains an 'island' where socialist legal ideologies largely dominate. These ideologies, associated with a traditional lecturing style, have equipped law students with rigid ideas about instrumentalist laws and the skill of rote learning. Current curricula still lead law students to simplify the legal system according to the Soviet model and elevate the importance of state control, no longer appropriate in a diverse, market-oriented economy.

The analysis has also shown a conflict between the mandatory teaching of socialist legal doctrines and the need to bring legal training closer to the market place. Reform has been made difficult by a variety of factors, including insufficient 
policy support, a Soviet institutional structure that promotes collective decisionmaking, and factors arising from the local culture.

Law students are not trained to practice in the legal profession. Established ideas about the various uses of law equip students with extensive knowledge of how the state can employ law to manage society, but impedes students' capacity to learn about non-state interests and perspectives. Young graduates nowadays are more attracted to the private sector (Nguyen 2002), but often face confusion and great difficulties when starting their careers owing to the nature of their training.

The state sector, with its entrenched psychology of 'state economic management', provides the ideal environment for such law graduates (AusAID 2000). Gillespie has noted that the collision of 'state economic management' ideas with forces for market liberalisation is creating tensions (Gillespie 2002). While the private sector demands greater market access, ministries and local authorites have sought to subvert government reforms and retain power by inventing new forms of control and intervention. ${ }^{56}$ The new generation of law graduates will be integral to this process in the future, holding the potential to slow or advance the reforms as they see fit.

It has been widely agreed that better legal education could ease the tensions. Improving teaching methodologies and skills for law teachers is a crucial issue that deserves more serious attention from policymakers. Detailed research of teachers' needs, and formal courses to address them, is likely to yield the best solutions. Such courses should aim at building up the analytical and problem-solving skills of law teachers because creative thinking amongst students will certainly not be promoted if the teachers themselves are not creative thinkers. Once the teachers' skills are upgraded, law students will immediately benefit from the improvements.

Established legal ideologies are not easily changed, but a training program (including curricula and course materials) with an orientation toward practice could make such ideologies less dogmatic. This approach also fits with the trend of the contemporary legal system towards a more pragmatic and rational approach, which would gradually help to improve the quality of legal education and thus reach the ambitious goals of reformers.

\section{NOTES}

1 Some law schools were established in China in the nineteenth century, and legal education in Poland dates back to the fourteenth century.

2 Mr Ngo Van Thau was one of a few professors at the Judicial Training School during the 1960s who speaks fluent French and often refers to French legal materials in his research work. However, his knowledge of the French legal system was obtained through self-learning rather than formal education. Interviewed in Hanoi, 2001. See also Sidel (1993).

3 In 1990, a small Faculty of Law was formed at the Ho Chi Minh City University by a group of Saigon attorneys who practised in Saigon before 1975. However, the curricula of this Faculty did not appear very different from other law schools. In addition, the Faculty itself is a controversial institution and not an influential participant in the local legal education market (Sidel 1993).

4 Decision No. 201/2001/QD-TTg dated 28 December 2001 of the Prime Minister Approving Education Development Strategy 2001-2010. 
5 In Vietnamese: 'Xay dung nen giao duc co tinh nhan dan, dan toc, khoa hoc, hien dai, theo dinh huong xa hoi chu nghia, lay chu nghia Mac-Lenin va tu tuong Ho Chi Minh lam nen tang'.

6 These include the National Economic University, Ho Chi Minh City University of Economy, University of Civil Construction, University of Commerce, University of Foreign Trade, University of Finance, University of Maritime and Vinh University (see Hanoi Law University 2002).

7 For example, the law team of Vinh University only has 3 lecturers. The Ho Chi Minh City University of Economy, in its ambitious expansion, is an exception in upgrading its law team (To) to faculty level (Khoa).

8 These include the Law Faculty of the Hanoi National University, Law Faculty of Can Tho University, Law Faculty of Da lat University and Law Faculty of the University of Science of Hue (see Hanoi Law University 2002).

9 There has been no formal survey that shows how fast the number of law graduates has increased during the last 15 years. Legal education has indeed become a 'phenomenon' and as a consequence, law training institutions have mushroomed. For example, in 1988, the Hanoi Law University had approximately 130 students enrolled in the undergraduate program. By December 2001, the University alone had issued Bachelor of Laws degree to 10,000 full-time students and 4,000 others were awaiting completion of their degrees (Hanoi Law University 2002). This is an impressive figure in light of the University's 22 years of education (Legal Need Assessment Report 2002).

10 For example, by the end of 2001, Hanoi Law University had 168 students enrolled in this type of course (Hanoi Law University 2002). The number has increased recently.

11 Hanoi Law University issued 18,000 'tai chuc' degrees by the end of 2001 and 7,000 others were in the process of completing the same degree (Hanoi Law University 2002).

12 Twenty-two years after the first formal law training institute was established, the country had 62,236 Bachelors of Laws nationwide (Legal Needs Assessment Report 2002).

13 By the end of 2001, Hanoi Law University alone had trained 314 LLM students (329 others were master candidates), $19 \mathrm{PhD}$ students (55 others were $\mathrm{PhD}$ candidates). It set an ambitious target that, by 2005, 70 per cent of the lecturers (232) would have an LLM, and 80 per cent would have that qualification by 2010 (with 50 per cent having a PhD) (Hanoi Law University 2002).

14 Newly opened schools, such as the Law Faculty of Can Tho University, seem to have more flexible curricula. However, the scale of these institutions is relatively small and the materials are still largely based on those prepared by Hanoi Law University and HCMCLU. See further Hanoi Law University (2002). Description of curricula applied in various law teaching institutions is also available in Sidel (1993).

15 The curriculum for in-service training is in fact an abbreviated form of the one used for fulltime students.

16 The length for an undergraduate course is four to five years.

17 For an example of curricula used in China, see Tay and Kamenka (1986). For Polish curricula, see Gostynski and Garfield (1993).

18 Decision No. 494/QD-TTg, dated 24 June 2002, of the Prime Minister. The MOET later issued an official letter that provides guidance to implement this Decision (Official Letter No. 7821/ CTCT, dated 5 September 2002). In addition, a series of MOET decisions set outlines for the subjects of Marxist-Leninist studies and Ho Chi Minh's thought.

19 Lecturing time is approximately 1,265 hours for general training and 3,265 hours for law training (Hanoi Law University 2002).

20 There are 13 law branches under the current system, among which banking law and environment law have been newly created. International law (including public and private law) is not regarded as a branch of domestic law, but rather as an independent law subject. See details in Le Minh Tam (1998e:399-403) and further discussion on the classification theory below.

21 There are four departments (Khoa) at the Hanoi Law University: Administrative Law (Phap Luat Hanh Chinh), Economic Law (Phap Luat Kinh Te), Judicial Studies (Tu Phap), and International Law (Phap Luat Quoc Te).

22 After completing the internship, the students are required to submit a brief report and then take a final exam. Internship is waived for those with good grades, who instead submit a graduate thesis.

23 The definition of law is as follows: 'Law is a system of norms that are codified and enforced by the state. It represents the will of the ruling class and is an instrument to adjust social relations 
(phap luat la he thong cac quy tac xu su do nha nuoc ban hanh va bao dam thuc hien, the hien y chi cua giai cap thong tri trong xa hoi, la nhan to dieu chinh cac quan he xa hoi)' (Le Minh Tam 1998b:64). This definition has been used for the last one and a half decades.

24 It is said that before reunification, the most important function of the state was national defence. This change in priorities shows that the state is now more concerned with economic development than national defence.

25 This concept of 'state economic management' has been renewed from time to time following Party policy reform. Most of the theory is drawn from Party resolutions.

26 The subject is often scheduled for first year students.

27 Legal scholars have tried to note the 'relative nature' (tinh chat tuong doi) of this classification and the interconnection between social relations.

28 For example, a joint-venture contract between a foreign investor and a Vietnamese entity.

29 Themes of State and Law contains only a few sentences naming the grounds to categorise law branches, without further analysis (Le Minh Tam 1998f).

30 The textbook is 559 pages long. Only four pages are dedicated to analysis of the relationship between law and other social spheres.

31 The MOET's design for the subject of Ho Chi Minh's thought includes one lesson on Ho Chi Minh's thought about state and law.

32 As part of ongoing reform, finance law was split into three smaller subjects at the end of 2004, namely budget law, tax law and insurance law.

33 State management of land, finance and banking are all subsets of 'state economic management'.

34 The Party's resolutions are the main source of references for Themes of State and Law. In fact, students learn about the development of state and law concepts through changes in Party policies.

35 One lecture often lasts for the whole morning or afternoon (four and a half hours), with a tenminute break every hour. Starting in Autumn 2001, one morning or afternoon session was divided into two subjects at Hanoi Law University. Lectures are often conducted in big halls, containing 100-200 students or more. Depending on the subject, one teacher may have to teach up to 20 hours per week.

36 They are, however, still large, with 70-80 students each.

37 This issue will be discussed at greater length below.

38 It should be noted that this is not only a legal education problem, but rather, a shortcoming of the entire Vietnamese education system. As an article in the Financial Times Information commented: 'teachers often paid too much attention to theoretical knowledge while neglecting practical application. Research institutes within universities and colleges were viewed as ivory towers that were isolated from both training activities and the real demand of the country's social and economic development' (Financial Times Information 2002). A senior official has also remarked on the situation that: 'science is up in the air, while life is down to earth' (khoa hoc tren troi, cuoc doi duoi dat), Available online at Vietnam Net, http://www.vnn.vn/442/2003/ $3 / 5081 /$.

39 Before the new regulations on lawyers were issued, a good network of personal relationships could make it relatively easy for law teachers to join the bar.

40 Articles 8 and 42, Ordinance on Lawyers, dated 25 July 2001.

41 Decision No. 153/2003/QD-TTg, dated 30 July 2003, of the Prime Minister Issuing By-Laws for Universities.

42 Article 46(2), Decision No. 153/2003/QD-TTg, dated 30 July 2003, of the Prime Minister Issuing By-Laws for Universities.

43 Decision No. 34/1998/QD-TTg, dated 11 February 1998, of the Prime Minister Setting up Legal Professional Training School. This school was established to provide on-the-job training for certain court positions, including judges. It was also extended to include courses on lawyer skills for those wishing to join the bar as private lawyers.

4 Decision No. 762/DT, dated 29 July 1999, of the Hanoi Law University Promulgating Curriculum for the Official Training Program at the Hanoi Law University.

45 Article 2, 1992 Constitution.

46 This proposed curricula readjustment would have certain economic consequences because teachers' income will decrease if they are given less lecturing time.

47 It has been acknowledged that the Legal Needs Assessment was an unprecedented government effort to assess the needs of the legal system in general, and legal education in particular. It 
showed the serious commitment of leaders to improve the country's legal system in order to facilitate economic and social development (McKinley 2002).

48 Informal interview with Ministry of Justice official and UNDP consultant.

49 Regulations on Control of International Co-operation in the Field of Administrative Reform were issued in conjunction with Decree No. 03/1999/ND-CP of the Government on 28 January 1999.

50 Decree No. 103/1998/ND-CP dated 26 December 1998 of the Government on Management of International Cooperation in the Legal Sector.

51 Decision No. 153/2003/QD-TTg dated 30 July 2003 of the Prime Minister Issuing By-Laws for Universities.

52 The Law on Promulgation of Legal Documents (Article 80) provides a number of principles to interpret legal documents with conflicting provisions. It is unclear how such principles are not applicable in this case.

53 See http://www.undp.org.vn/projects/legal/nofive/ and http://vnexpress.net/Vietnam/ Xa-hoi/Giao-duc/2001/.

54 Quiz competitions have become a popular social activity in contemporary Vietnam. At Hanoi Law University, a law-teaching unit (to) may have a quiz competition for law students focusing on the subject taught by that unit. Such events are often jointly organised with the Youth Union (Doan Thanh Nien) or Students Union (Hoi Sinh Vien), as these organisations are in charge of social activities for students.

55 Seminar on Reforming Economic Law, Hanoi Law University: Summer 2002.

56 For further discussion on the implications of 'state economic management' and bureaucratic culture, see AusAID (2000).

\section{REFERENCES}

AusAID, 2000. Vietnam: legal and judicial development, AusAID, Canberra. Available online at www.ausaid.gov.au/publications/.

Communist Party of Vietnam, 2001. Education System in Vietnam, Communist Party of Vietnam, Hanoi. Available online at http:/ /www.cpv.org.vn/nghiencuu / daihoi9/theky21/docs/3.htm.

Depei, H. and Kanter, S., 1984. 'Legal education in China', American Journal of Comparative Law, 32(3):543-82.

Financial Times Information 2002. 'Labour and Education: Vietnam Education Fails Because of Half-Copied Models', Global Newws Wire-Asia Africa Intelligence Wire, Financial Times Information, 11 October. Reproduced at http:// www.undp.org.vn/mlist/cngd/102002/post4.htm.

Gillespie, J., 2002. 'Transplanted company law: an ideology and cultural analysis of market-entry in Vietnam', International and Comparative Law Quarterly, 51(3):64172.

Gostynski, Z. and Garfield, A., 1993. 'Taking the other road: Polish legal education during the past thirty years', Temple International and Comparative Law Journal, 7(2):243-86.

Hanoi Law University, 2002. Report on Survey of Legal Training in Vietnam, Seminar on Legal Education, Hanoi Law University, Hanoi, 26-27 September.

Ho Chi Minh City University of Economics, 2001. Celebrating Twenty-Five Years of Education of Economic University of Ho Chi Minh City, Ho Chi Minh City University of Economics, Ho Chi Minh City. Available online at http:// www.hcmueco.edu.vn/bantin/bantin73/w8.htm. 
Kelly, K., 2000. 'The higher education system in Vietnam', E-World Education News and Reviews, 13(3):n.p. Available online http:/ / www.wes.org/ewenr/00may / feature.htm.

Le Minh Tam, 1998a. 'Doi Tuong va Phuong Phap Nghien Cuu Cua Ly Luan Ve Nha Nuoc va Phap Luat [Scope and methodology for studying the themes of state and law]' in Hanoi Law University (ed.), Giao Trinh Ly Luan Nha Nuoc Va Phap Luat [Textbook on Themes of State and Law], Nha Xuat Ban Cong An Nhan Dan, Hanoi:5-24.

, 1998b. 'Ban Chat, Dac Trung, Vai Tro, Cac Kieu va Hinh Thuc Phap Luat [Nature, Features, Roles, Types and Forms of Laws]' in Hanoi Law University (ed.) Giao Trinh Ly Luan Nha Nuoc Va Phap Luat [Textbook on Themes of State and Law], Nha Xuat Ban Cong An Nhan Dan, Hanoi:61-82.

_ , 1998c. 'Cac Chuc Nang Co Ban Cua Nha Nuoc Xa Hoi Chu Nghia [Main Functions of Socialist States]' in Hanoi Law University (ed.), Giao Trinh Ly Luan Nha Nuoc Va Phap Luat [Textbook on Themes of State and Law], Nha Xuat Ban Cong An Nhan Dan, Hanoi:221-42.

, 1998d. 'Cac Hinh Thuc Nha Nuoc Xa Hoi Chu Nghia [Forms of Socialist States], in Hanoi Law University (ed.), Giao Trinh Ly Luan Nha Nuoc Va Phap Luat [Textbook on Themes of State and Law], Nha Xuat Ban Cong An Nhan Dan, Hanoi:243-56.

_ 1998e. 'Ban Chat, Vai Tro, va He Cac Nguyen Tac Co Ban Cua Phap Luat Xa Hoi Chu Nghia [Nature, Role and Fundamental Principles of Socialist Law]', in Hanoi Law University (ed.), Giao Trinh Ly Luan Nha Nuoc Va Phap Luat [Textbook on Themes of State and Law], Nha Xuat Ban Cong An Nhan Dan, Hanoi:329_ 52.

, 1998f. 'He Thong Phap Luat Xa Hoi Chu Nghia [The Socialist Legal System], in Hanoi Law University (ed.), Giao Trinh Ly Luan Nha Nuoc Va Phap Luat [Textbook on Themes of State and Law], Nha Xuat Ban Cong An Nhan Dan, Hanoi:393-414.

Macdonald, R.St.J., 1980. 'Legal education in China today', Dalhousie Law Journal, 6(2):313-17.

McKinley, C., 2002. 'In Vietnam, laws are made to be broken', Dow Jones Newswire, 29 October. Available online at http:/ / www.usvtc.org/News/2002/.

Nguyen, P.A., 2002. 'Looking beyond Bien Che: the consideration of young Vietnamese graduates when seeking employment in the Doi Moi era', Sojoun: journal of social issues in Southeast Asia, 17(October):221-48.

Quinn, B., 2002. 'Legal Reform and Its Context in Vietnam', Journal of Asian Law, 15(2):219-93. Available online at http://www.columbia.edu/cu/asiaweb/ JAL001.htm.

Sidel, M., 1993. 'Law reform in Vietnam: the complex transition from Socialism and Soviet models in legal scholarship and training', Pacific Basin Law Journal, 11(2):221-59.

Tay, A.E and Kamenka, E., 1986. 'Law, legal theory and legal education in the People's Republic of China', New York Law School Journal of International and Comparative Law, 7(1):1-38. 
Tran Quang Huy, 2001a. 'Khai Niem Chung Ve Nganh Luat Dat Dai [Overview of the Land Law Branch]' in Hanoi Law University (ed.), Giao Trinh Luat Dat Dai [Textbook on Land Law], Nha Xuat Ban Cong An Nhan Dan, Hanoi:5-24.

_ - 2001b. 'Che Do So Huu Toan Dan Doi Voi Dat Dai [The Regime of People's Ownership with Respect to Land], in Hanoi Law University (ed.), Giao Trinh Luat Dat Dai [Textbook on Land Law], Nha Xuat Ban Cong An Nhan Dan, Hanoi:47-76.

, 2001c. 'Che Do Quan Ly Nha Nuoc Doi Voi Dat Dai [The Regime of State Management with Respect to Land]' in Hanoi Law University (ed.), Giao Trinh Luat Dat Dai [Textbook on Land Law], Nha Xuat Ban Cong An Nhan Dan, Hanoi:77-110.

Vo Dinh Toan, 2002. 'Nhung Van De Ly Luan [Major Theoretical Issues about Vietnamese Banking Law]', in Hanoi Law University (ed.), Giao Trinh Luat Ngan Hang [Textbook on Banking Law], Nha Xuat Ban Cong An Nhan Dan, Hanoi:524.

Zamboni, M., 2001. "Rechtsstaat": just what is being exported by Swedish development organisations?', Law, Social Justice E Global Development Journal, 2001(2):n.p. Available online at <http:/ / elj.warwick.ac.uk/global/issue/20012/zamboni.html>. 